tion, since they give proof that the bees know how to help themselves under all circumstances, that they understand how to overcome any obstacle. The most irregular cell in the bee-hive is the queenbee cell, in which, as is well known, the queen has to pass her youthful stages. This queen-bee cell is shaped like an acorn, and does not stand horizontally like all the other bee cells, but hangs vertically, with the opening downward.

These few quite imperfect remarks may serve to call attention to some of the so numerous irregularities among insects. I hope they may incite others to further new and more interesting observations.

Leipzig, ${ }_{5}$ Fune 1884.

\title{
FOOD-PLANTS OF BEETLES BRED IN MARYLAND.
}

\author{
BY OTTO LUGGER, BALTIMORE, MD,
}

[The numeros (inserted by the editor) are, for the coleoptera, those of $\mathbf{G}: \mathbf{R}$. Crotch's "Check list of the coleoptera of America, north of Mexico" (Psxche, Rec., no. 43), and, for the food plants, those of Horace Mann's "Catalogue of the phaenogamous plants of the United States" .... Where the species of the food.plant is not stated, the numero expresses a conjecture.]

BUPRESTIDAE.

369ז. Dicerca pugionata

3726. Buprestis apricans

3767. Chrysobothris azurea

3799. Ptosima gibbicollis

3801. Mastogenius subcyaneus

3814. Agrilus lecontei

$3^{825}$. " " politus

Elateridae.

3863. Tharops obliquus

426o. Corymbites vernalis

43 Iо. "6 hamatus

RHIPICERIDAE.

4374. Sandalus petrophya.

Cerambycidae.

4925. Sphenostethus taslei

4941. Smodicum cucujiforme

4943. Dularius brevitineus
2574. Quercus alba.

2658. Pinus mitis.

2579. Quercus coccinea var. tinctoria.

705. Cercis canadensis.

2603. Ostrya virginica.

r053? Cornus [florida?].

575. Robinia pseudacacia (spines).

2600. Fagus ferruginea.

2660? Pinus? [strobus?].

447. Rhus toxicodendron.

2574. Quercus alba.

2574. Quercus alba.

262 I? Salix [alba?]

$253^{8}$ ? Ulmus [americana?]. 
4970. Oeme rigida

4977. Gracilia minuta

5015. Elaphidion unicolor

5025. Tylonotus bimaculatus

5047. Molorchus bimaculatus

5070. Purpuricenus humeralis

5070a. " " var. axillaris

5III. Calloides nobilis

5II3. Arhopalus fulminans

5144. Cyrtophorus gibbulus

5145 . "6 verrucosus

5146. Tillomorpha geminata

5155. Distenia undata

5166. Centrodera decolorata

5225. Leptura emarginata

5253. " " zebra

$525^{6}$. " 6 cordifera

5331. Hetoemis cinerea

5343. Acanthoderes morrisii

5381. Dectes spinosus

5405. Hippopsis lemniscata

5457. Dysphaga tenuipes

Spermophagidae.

5464. Bruchus mimus
2658. Pinus mitis.

26ro. Betula lenta (band around gin. barrel).

2595. Quercus rubra.

2563. Juglans nigra.

r053? Cornus [florida?] ; 818. Amelanchier canadensis.

498? Acer [dasycarpum?].

2579. Quercus coccinea var. tinctoria.

23r6? Fraxinus [americana?].

-. Quercus.

2574. Quercus alba.

2574 . 6 6 6

2574. 66 6

2. Pyrus malus.

- Carya.

2536. Ulmus fulva.

2593. Quercus prinus.

2598. Castanea vesca.

-. Maclura aurantiaca. - Morus.

го6r. Nyssa multiflora.

- Ambrosia.

- Ambrosia.

2574. Quercus alba.
Effect of Cyanide upon Colour. - A very curious case of artificial colouring in a butterfly has been sent me by a friend. He says that the specimen, a male Gonopteryx [sic] rhamni, was placed in a spare cyanide bottle, and left undisturbed for two years; but that, at some intermediate time, the stopper was tampered with and not properly replaced, so that air was introduced. The result is, that the butterfly is richly coloured with crimson along the costal area, and partially round the other margins of the fore-wings, and has large blotches of the same on the hind-wings. Indeed, the only portion of the wings which is left entirely of the usual brimstone colour is that portion which, in $G$. cleopatra, is clouded with crimson.Chas. G. Barrett, Pembroke : 9th April, I884. [From Entom. mo. mag., June I 884 , v. 2 I, p. 23.] 

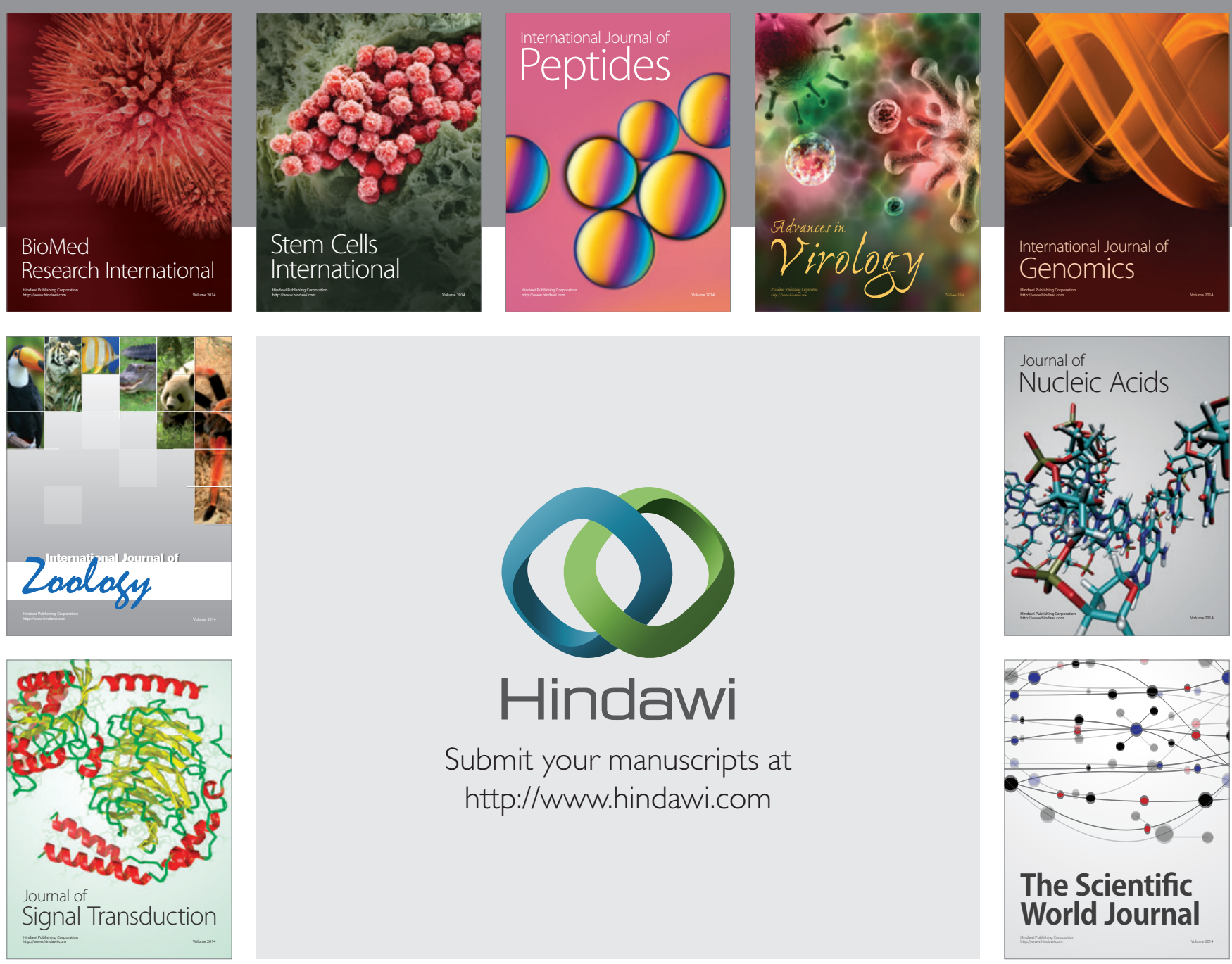

Submit your manuscripts at

http://www.hindawi.com
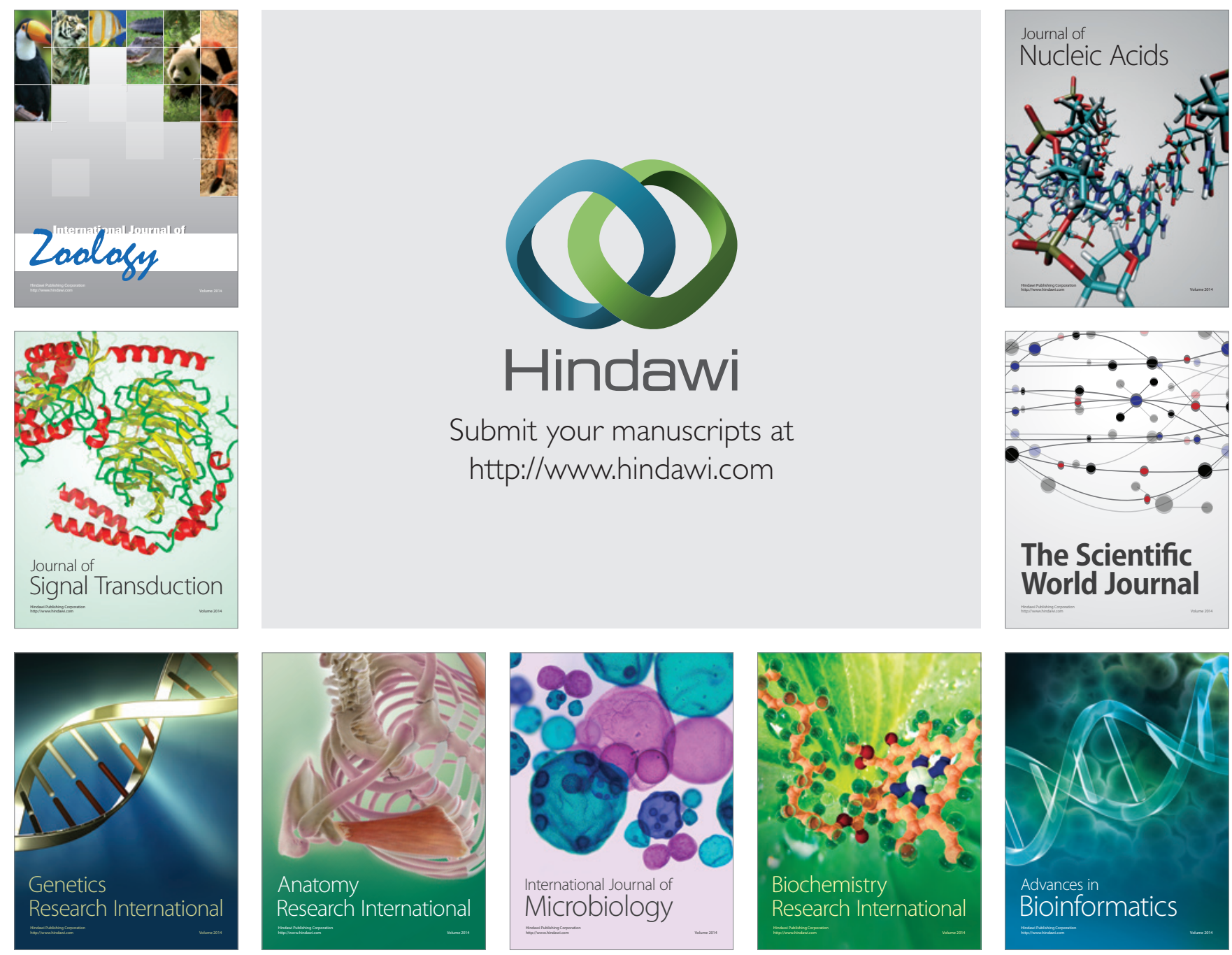

The Scientific World Journal
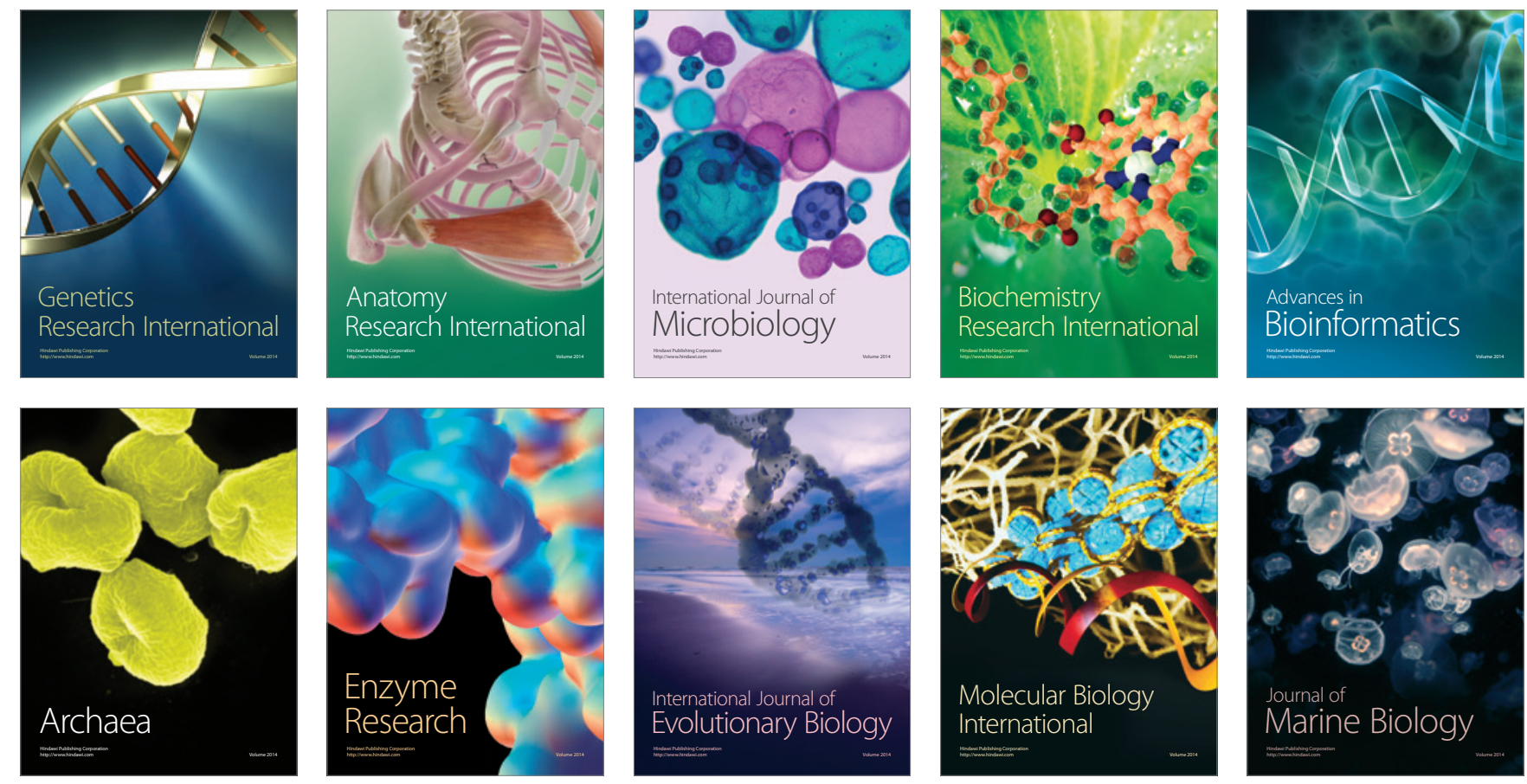